\title{
Penerapan Tata Cara Pencabutan Pengukuhan PKP Sesuai Peraturan Diitjen Pajak Nomor 12 Tahun 2014 Pada KPP Pratama Manado
}

\author{
Oleh : \\ Virgie Mangare \\ Fakultas Ekonomi dan Bisnis Jurusan Akuntansi \\ Universitas Sam Ratulangi Manado \\ Email: virgiemangare@gmail.com
}

\begin{abstract}
Tax is playing important role in economy of the country. Today, number of firms from big to small many have not been listed to KPP Pratama Manado. Directorate General of Taxation Issues rule No.12 Tahun 2014 in order to grouping the sales limit and simplified the administration and controlling. Many business sector listed but have not been revocation and have sales under Rp. 4,8 Billion. The purpose if this research is to knowing that the application of rules Directorate General of Taxation No.12 Tahun 2014. Data analysis method uses is descriptive. To know the limit of the sales it need income statement. Tax fare and calculation method of income tax. The difference of tax which is deposited is quite large. The application of PP No.46 Tahun 2013 is really profitable because income tax which must be deposited is much smaller. Meaning the new rules is much simpler, and to make the government more easier to grouping the sales limit and the revocation of taxable enterprise. To improve service and improve administratif simplification as well as controling. KPP Pratama Manado should be more sosializing the new regulations.
\end{abstract}

Keywords: Tax, Sales limit, Taxable enterprise

\section{PENDAHULUAN}

Sistem kenegaraan Indonesia, pajak merupakan tulang punggung pembiayaan pelaksanaan pembangunan. Pajak sangat berperan dalam menggerakkan roda perekonomian. Masyarakat sebagai wajib pajak berfungsi untuk sumber dana bagi pemerintah dalam membiayai pengeluarannya. Indonesia menggunakan pajak sebagai sumber utama penerimaan negara. Pajak merupakan sumber penerimaan negara untuk membiayai semua pengeluaran. Pemberian kesempatan serta wewenang kepada wajib pajak untuk melaksanakan kewajiban perpajakannya.

Pajak Pertambahan Nilai (PPN) merupakan salah satu beban pajak yang harus dipenuhi atau dibayarkan oleh Wajib Pajak. Kewajiban tersebut diharapkan dapat menambah penerimaan negara dari sektor perpajakan. Dalam perkembangannnya, perekonomian Indonesia telah didominasi oleh berbagai kegiatan usaha. Pemerintah telah melakukan sensus pajak guna mendata wajib pajak potensial. Pejabat Direktorat Jenderal Pajak (DJP) menyatakan pengenaan pajak bagi pengusaha kena pajak ditujukan dalam rangka proses pembelajaran.

Negara berkembang, ambang batas omset menjadi PKP di Indonesia rata-rata hampir sama dengan negara berkembang lainnya. Berdasarkan peraturan Menteri Keuangan No.197/PMK.03/2013 tentang perubahan atas peraturan Menteri Keuangan No.68/PMK.03/2010 tentang batasan pengusaha kecil atas pengenaan pajak pertambahan nilai (PPN), telah diubah menjadi tidak lebih dari Rp. 4.800.000.000,00 (empat milyar delapan ratus juta rupiah). Jumlah Pengusaha Kena Pajak terdaftar dengan omset kurang dari Rp. 4,8 
milyar per tahun masih sangat banyak, sehingga dalam penyederhanaan administrasi pajak pertambahan nilai serta untuk meningkatkan pelayanan dan pengawasan.

Kantor Pelayanan Pajak Pratama Manado telah menerapkan peraturan pencabutan pengukuhan Pengusaha Kena Pajak secara jabatan atas pengusaha kecil pajak pertambahan nilai tahun 2014. Dari hal tersebut sangat mempengaruhi keadaan penerimaan pajak yang ada. Untuk menerapkan pencabutan PKP ini, tidaklah mudah untuk dilakukan karena banyak pengusaha yang belum memahami peraturan tersebut. Mereka mungkin sudah meraup omset ratusan juta hingga miliaran rupiah, tapi kontribusi pajaknya sedikit. Pengusaha Kecil Menengah dengan omset berkisar Rp. 300 juta - Rp. 4,8 miliar akan dikenakan PPh 1\% dan PPN 1\%. Terkait itu, penurunan batas maksimal omset PKP dari Rp. 600 juta menjadi Rp. 300 juta diharapkan dapat menjaring lebih banyak PKP berpendapatan Rp. 300 juta ke atas.

Direktorat Jenderal Pajak telah mengeluarkan kebijakan baru bagi pelaku pengusaha kecil menengah. Peraturan ini ditujukan kepada Pengusaha kecil Pajak Pertambahan Nilai (PPN) dalam rangka penyederhanaan administrasi Pajak Pertambahan Nilai serta untuk meningkatkan pelayanan dan pengawasan Pengusaha Kena Pajak perlu dilakukan verifikasi secara serentak dalam rangka pencabutan pengukuhan Pengusaha Kena Pajak secara jabatan atas Pengusaha Kecil Pajak Pertambahan Nilai. Ini merupakan peraturan baru yang dikeluarkan oleh Direktur Jendral Pajak Nomer PER-12/PJ/2014. Kantor pelayanan pajak membuat daftar pengusaha kena pajak terdaftar per tanggal 1 Januari 2014 berdasarkan pelaporan SPT Masa PPN yang memiliki jumlah nilai peredaran brutonya selama pajak Januari 2013 sampai dengan masa pajak Desember 2013 tidak lebih dari Rp. 4,8 miliar.

Tujuan penelitian ini adalah untuk mengetahui Penerapan Tata Cara Pencabutan Pengukuhan PKP Sesuai Peraturan Direktur Jenderal Pajak Nomor PER-12/PJ/2014.

\section{TINJAUAN PUSTAKA}

Mardiasmo (2013:1) mendefinisikan Pajak adalah iuran rakyat kepada Negara berdasarkan Undang-Undang (dapat dipaksakan) dengan tiada mendapat jasa timbal-balik (kontra prestasi) langsung dapat ditujukan dan digunakan untuk membayar pengeluaran umum. Pasal 1 UU No. 28 Tahun 2007 tentang ketentuan umum dan tata cara perpajakan, pajak adalah kontribusi wajib kepada negara terutang oleh orang pribadi/badan bersifat memaksa berdasarkan Undang-Undang dengan tidak mendapat timbal-balik secara langsung dan digunakan untuk keperluan negara bagi kemakmuran rakyat.

Waluyo (2011:2) mendefinisikan pajak adalah iuran kepada negara (yang dapat dipaksakan) yang terutang oleh yang wajib membayarnya menurut peraturan-peraturan, dengan tidak mendapat prestasi kembali, yang langsung dapat ditunjuk, dan yang gunanya adalah untuk membiayai pengeluaran-pengeluaran umum berhubung dengan tugas negara yang menyelenggarakan pemerintahan.

Mardiasmo (2013:10), menyebutkan fungsi pajak terbagi dua, yaitu:

1. Fungsi Budgetair yaitu pajak sebagai sumber dana bagi pemerintah untuk membiayai pengeluaran-pengeluarannya.

2. Fungsi Regulerend yaitu pajak sebagai alat untuk mengatur atau melaksanakan kebijakan pemerintah dalam bidang sosial dan ekonomi.

Waluyo (2011:6) menyebutkan ciri-ciri yang melekat pada pengertian pajak dari berbagai definisi, terbagi dua fungsi pajak sebagai berikut:

1. Fungsi Penerimaan (Budgeter)

Pajak berfungsi sebagai sumber dana yang diperuntukan bagi pembiayaan pengeluaranpengeluaran pemerintah

2. Fungsi Mengatur (Reguler) 
Pajak berfungsi sebagai alat untuk mengatur/melaksanakan kebijakan dibidang sosial dan ekonomi.

Mardiasmo (2013:293) menjelaskan Pajak Pertambahan Nilai merupakan pengganti dari pajak penjualan dan Pajak Penjualan yang dipunggut atas dasar nilai tambah (value added) yang timbul pada semua jalur produksi dan distribusi.

Resmi (2012:1) menjelaskan dasar hukum Pajak Pertambahan Nilai adalah Undangundang Nomor 8 Tahun 1983 tentang Pajak Pertambahan Nilai dan Pajak Penjualan atas Barang Mewah sebagaimana telah diubah dengan Undang-undang Nomor 11 Tahun 1994, diubah lagi dengan Undang-undang Nomor 18 tahun 2000, dan terakhir Undang-undang Nomor 42 Tahun 2009.

Waluyo (2011:71) menjelaskan Pengusaha Kena Pajak adalah Pengusaha yang melakukan penyerahan Barang Kena Pajak dan atau penyerahan Jasa Kena Pajak yang dikenakan pajak. Berdasarkan Undang-Undang Pajak Pertambahan Nilai, tidak termasuk Pengusaha Kecil yang batasannya ditetapkan oleh Menteri Keuangan, kecuali Pengusaha Kecil yang memilih untuk dikukuhkan menjadi Pengusaha Kena Pajak.

Resmi (2012:4) mendifinisikan pengusaha sebagaimana dimaksud dalam Nomor 14 yang melakukan penyerahan BKP dan/atau Penyerahan JKP yang dikenakan pajak berdasarkan Undang-Undang PPN dan PPnBM, tidak termasuk Pengusaha kecil yang batasannya ditetapkan dengan keputusan Menteri Keuangan, kecuali Pengusaha kecil yang memilih untuk dikukuhkan sebagai Pengusaha Kena Pajak.

Waluyo (2011:72) menjelaskan bahwa dalam rangka pelaksanaan pelaporan kegiatan usaha, pengusaha dikukuhkan menjadi Pengusaha Kena Pajak, berdasarkan keputusan Direktorat Jenderal Pajak No.Kep.16/Pj/2001 tanggal 21 Febuari 2001, yaitu:

1. Tempat pelaporan kegiatan usaha

2. Tempat pelaporan usaha bagi pengusaha kena pajak tertentu adalah pengusaha kena pajak badan usaha milik Negara dan badan usaha milik daerah, penanaman modal asing, badan dan orang asing dan perusahan masuk bursa

3. Batas waktu pelaporan usaha untuk dikukuhkan menjadi PKP adalah selambat-lambatnya 1 bulan setelah usaha dimulai atau saat pendirian usaha

Peraturan Dirjen Pajak PER-12/PJ/2014 TANGGAL 2 APRIL 2014, bagi pengusaha kecil yang peredaran brutonya tidak melebihi Rp. 4,8 Miliyar akan dicabut PKPnya. Mengenai isi dari PER-12/PJ/2014 dapat disimpulkan sebagai berikut :

1. PER-12/PJ/2014 diterbitkan untuk mengatur secara khusus pencabutan pengukuhan pengusaha kena pajak (PKP) secara jabatan atas pengusaha kecil pajak pertambahan nilai tahun 2014.

2. Pengusaha Kecil PPN yang peredaran brutonya selama tahun 2013 tidak melebihi Rp. 4,8 Milliar akan dicabut pengusaha kena pajak (PKP) nya.

3. Dirjen pajak tidak akan mencabut PKP selama pengusaha kecil pajak pertambahan nilai tetap memilih sebagai pengusaha kena pajak (PKP).

4. Pencabutan pengukuhan Pengusaha Kena Pajak secara jabatan sebagaimana dimaksud dilakukan dengan cara memverifikasi pengusaha kecil pajak pertambahan nilai yang peredaran brutonya selama tahun 2013 tidak melebihi Rp. 4,8 milliar.

5. Verifikasi dilakukan oleh Account Representative (AR) atau Pelaksana, yang ditunjuk oleh Kepala Kantor Pelayanan Pajak dengan membawa surat tugas yang dilakukan sampai pada tanggal 31 Agustus 2014.

6. Membuat daftar pengusaha kecil pajak pertambahan nilai yang memilih untuk dilakukan pencabutan sebagai PKP dan yang tidak menyampaikan surat pernyataan sampai dengan tanggal 31 Mei 2014.

Butar Butar (2013) dari Universitas Brawijaya Malang mengenai Penerapan PP NO.46 Tahun 2013 Pada UMKM. Tujuan penelitian adalah untuk mengetahui dampak penerapan PP 
No.46 Tahun 2013 terhadap besarnya PPh Badan yang harus dibayar oleh perusahaan. Dalam penelitian ini, menggunakan metode penelitian deskriptif kualitatif melalui pengumpulan data. Hasil dari penelitian ini adalah penerapan peraturan baru memberikan kemudahan dalam menghitung besarnya PPh terhutang sehingga meminimalisir terjadinya kesalahan dalam menentukan besarnya PPh badan yang harus disetor.

Arsita (2013) mengenai Analisis Rencana Perubahan Batas Omset Pengusaha Kena Pajak atas Pengenaan Pajak Pertambahan Nilai Usaha Kecil Menengah. Tujuan penelitian ini adalah untuk mengidentifikasi dan menganalisis latar belakang perubahan kebijakan atas omset pertahun menjadi PKP dan UKM. Metode yang digunakan deskriptif dengan pendekatan penelitian kualitatif deskriptif. Hasil penelitian untuk menyederhanakan pemajakan PPN pada UKM dan menyesuaikan dengan laju inflasi untuk menggairakan perekonomian negara. Jumlah penerimaan tergantung pada perubahan naik atau turunnya batas omset PKP. Pemerintah sebaiknya memberikan pengawasan pada UKM sehingga dapat menetapkan ketentuan kebijakan batas omset ideal.

\section{METODE PENELITIAN}

\subsection{Data}

Tipe penelitian yang digunakan dalam penelitian ini yaitu tipe penelitian deskriptif, dimana tipe penelitian deskriptif adalah jenis penelitian yang menganalisis data dengan cara mendeskripsikan atau menggambarkan data yang terkumpul, dan tanpa membuat kesimpulan yang berlaku umum (generalisasi).

Penelitian mengenai Analisis Penerapan Peraturan Direktorat Jenderal Pajak Nomor PER- 12/PJ/2014 dilakukan pada Kantor Pelayanan Pajak Pratama Manado jalan Gunung Klabat No.17 Manado dari bulan November sampai Desember 2014.

Metode pengumpulan data menurut Sugiyono (2010:14), terbagi dua yaitu:

1. Metode Kualitatif

Metode Penelitian berlandaskan pada filsafat pospositivisme, digunakan untuk meneliti pada objek alamiah, (sebagai lawannya adalah eksperimen) dimana peneliti adalah sebagai instrument kunci, pengambilan sampel data yang dilakukan secara purposive dan snowbaal, teknik pengumpulan dengan trianggulasi (gabungan), analisis data bersifat induktif/kualitatif, dan hasil penelitian kualitatif lebih menekankan makna dari pada generalisasi.

2. Metode Kuantitatif

Metode Kuantitatif dapat diartikan sebagai metode penelitian yang berlandaskan pada filsafat positivisme untuk meneliti pada populasi atau sampel tertentu, teknik pengambilan sampel pada umumnya dilakukan secara random, pengumpulan data secara instrument, penelitian, analisis data bersifat kuantitatif/statistik dengan tujuan untuk menguji hipotesis yang telah ditetapkan.

Sumber data menurut Indriantoro (2009:155) terbagi dua, yaitu:

1. Data Primer adalah sumber data penelitian yang diperoleh secara langsung dari sumber asli

2. Data Sekunder adalah sumber data yang diperoleh peneliti secara tidak langsung melalui media perantara

\subsection{Metode Analisis}

Penelitian ini menggunakan teknik analisis data kualitatif. Analisis data merupakan bagian amat penting dalam metode ilmiah, karena dengan analisis data tersebut dapat diberi arti dan makna yang berguna dalam memecahkan masalah penelitian. Analisis data merupakan proses lanjutan dari proses pengolahan data, untuk melihat bagaimana menginterpretasikan data dan menganalisis data dari hasil yang sudah ada. 


\section{HASIL ANALISIS DAN PEMBAHASAN}

\subsection{Hasil Analisis}

Kantor Pelayanan Pajak Pratama Manado yang beralamat Jalan Gunung Klabat No. 17 Manado, merupakan Instansi Vertikal Direktorat Jenderal Pajak di bawah Kantor Wilayah DJP Sulawesi Utara, Tengah, Gorontalo dan Maluku yang bernaung di bawah Departemen Keuangan Republik Indonesia. Tugas dari Kantor Pelayanan Pajak Pratama Manado adalah melaksanakan tugas pokok Direktorat Jenderal Pajak dalam menghimpun penerimaan Negara dari sektor perpajakan.

KPP Pratama Manado melaksanakan pencabutan pengukuhan pengusaha kena pajak secara jabatan atas pengusaha kecil pajak pertambahan nilai tahun 2014 berdasarkan Peraturan Menteri Keuangan Nomor 197/PMK.03/2013 tentang Perubahan atas Peraturan Menteri Keuangan Nomor 68/ PMK.03/2010 tentang Batasan omset Pengusaha Kecil Pajak Pertambahan Nilai, telah diubah menjadi tidak lebih dari Rp. 4.800.000.000,00 (empat milyar delapan ratus juta rupiah).

Jumlah PKP yang terdaftar salah satunya UD.Indah Jaya Perkasa merupakan perusahaan yang belum melakukan pengukuhan pengusaha kena pajak secara jabatan. UD.Indah Jaya Perkasa merupakan contoh objek untuk mengetahui peredaran bruto, tarif pajak, metode perhitungan dan PPh terutang yang digunakan UD.Indah Jaya Perkasa. Yang bertujuan untuk mengetahui UD.IJP memiliki batasan omset sesuai peraturan Direktorat Jenderal Pajak Nomor PER-12/PJ/2014.

Tabel 1. Data Total PKP Omset dibawah Rp. 4,8 M KPP Pratama

\begin{tabular}{lc}
\multicolumn{1}{c}{ Uraian } & Jumlah \\
\hline Jumlah total PKP KPP Pratama Manado & 4.405 \\
Jumlah PKP omset dibawah Rp.4,8 M & 3.317 \\
Tetap PKP & 172 \\
PKP dicabut & 76 \\
\hline
\end{tabular}

Sumber :KPP Pratama Manado, 2014

Peraturan Direktorat Jenderal Pajak Nomor PER-12/PJ/2014 menjelaskan bahwa pengusaha kecil yang dikukuhkan sebagai PKP dengan batasan omset dibawah Rp. 4,8 Miliar dikenakan pajak $1 \%$ dari omset pertahun. 
Table 2. Data Pendapatan UD.Indah JayaPerkasa

\begin{tabular}{lc}
\hline Bulan & $\begin{array}{l}\text { Pendapatan } \\
\text { Bruto/Omset }\end{array}$ \\
\hline Januari & Rp. 152.165 .245 \\
Februari & Rp. 126.580 .256 \\
Maret & Rp. 225.445 .320 \\
April & Rp. 248.880 .566 \\
Mei & Rp. 155.688 .080 \\
Juni & Rp. 159.996 .650 \\
Juli & Rp. 112.183 .451 \\
Agustus & Rp. 140.742 .535 \\
September & Rp. 127.538 .057 \\
Oktober & Rp. 117.607 .858 \\
November & Rp. 131.171 .536 \\
Desember & Rp. 121.458 .544 \\
\hline
\end{tabular}

TOTAL

Rp. 1.819.458.098

Sumber: UD.Indah Jaya Perkasa, 2014

Perhitungannya omset dibawah Rp. 4,8 Miliar menggunakan tarif $1 \% \mathrm{PPh}$ final. Berikut adalah hitungan PPh 1\% final UD.Indah Jaya Perkasa Rp. $1.819 .458 .098 \times 1 \%=\mathrm{Rp}$. 18.194.581

Perhitungan menunjukan bahwa UD.Indah Jaya Perkasa memiliki omset dibawah Rp. 4,8 $\mathrm{M}$ dan telah menggunakan tarif $1 \%$ final. Berdasarkan data tersebut, titik acuan untuk menentukan tarif pajak sebagai berikut berdasarkan peraturan tarif pajak $\mathrm{PPh}$ pasal 25 Undang-Undang No.36 tahun 2008.

Table 3. Tarif Pajak Penghasilan UU No.36 Tahun 2008

\begin{tabular}{lc}
\hline Lapisan Penghasilan Kena Pajak & Tarif \\
\hline Sampai dengan Rp. 50.000.000,- & $5 \%$ \\
Di atas Rp. 50.000.000,- sampai dengan Rp. 250.000.000,- & $15 \%$ \\
Di atas Rp. 250.000.000,- sampai dengan Rp. 500.000.000,- & $25 \%$ \\
Di atas Rp. 500.000.000,- & $30 \%$
\end{tabular}

Sumber: Waluyo (2012:195) Akuntansi Pajak edisi empat

Peraturan pemerintah No.46 Tahun 2013 adalah peraturan baru yang mengatur besarnya pajak terutang atas penghasilan wajib pajak dengan peredaran bruto tertentu dalam tahun pajak. Peraturan ini bersifat final dengan tarif $1 \%$.

Metode perhitungan yang digunakan pada PPh Pasal 25 (UU No.36 Tahun 2008) dengan laba UD.Indah Jaya Perkasa sejumlah Rp. 433.031.027 tahun 2014 yaitu: 
Laba $\times$ Tarif Pajak

Rp. $50.000 .000 \times 5 \%=$ Rp. 2.500 .000

Rp. $200.000 .000 \times 15 \%=$ Rp. 30.000 .000

Rp.183.031.027 x 25\% = $\underline{\text { Rp. } 45.757 .757}$

Rp. 78.257 .757

Table 4. Perbandingan PPh TERHUTANG

\begin{tabular}{lccc}
\hline Tahun & $\begin{array}{c}\text { PPh Pasal 25 } \\
\text { (UU No.36 tahun 2008) }\end{array}$ & PP No.46 Tahun 2013 & Selisih \\
\hline 2014 & Rp. 78.257.757 & Rp. 18.194.581 & Rp. 60.063.176
\end{tabular}

Sumber: Peraturan Pajak UU No. 36 tahun 2008 pasal 25 dan PP No. 46 tahun, 2013

Data perbandingan menunjukan selisih $\mathrm{PPh}$ yang disetor ke negara adalah sebesar Rp. 60.063.176. Penerapan PP No.46 Tahun 2013 pada UD.Indah Jaya Perkasa sangat menguntungkan karena $\mathrm{PPh}$ yang harus disetor lebih kecil. Membuktikan peraturan baru menjadi lebih sederhana. Penelitian ini membantu UD.Indah Jaya Perkasa dalam menerapkan perhitungan $\mathrm{PPh}$ Badan sesuai dengan peraturan perundang-undangan pajak yang berlaku dan membantu pemerintah dalam penggelompokan pengenaan pajak yang digunakan untuk peredaran bruto sesuai dengan batasan omset dibawah Rp. 4,8 Miliar. Selain penerimaan negara menjadi lebih pasti, kesederhaaan administrasi juga tercapai walaupun UD.Indah Jaya Perkasa merupakan salah satu perusahaan yang belum melakukan pencabutan pengukuhan Pengusaha Kena Pajak secara jabatan. Hal ini sangat membantu pemerintah dalam aspek pengawasan.

\subsection{Pembahasan}

Pelaksanaan verifikasi dalam rangka pencabutan pengukuhan pengusaha kena pajak secara jabatan bertujuan melakukan pengujian jumlah nilai peredaran bruto dan/atau penerimaan bruto, tarif pajak, metode perhitungan, jumlah PPh terutang selama Masa Pajak Januari tahun 2013 sampai dengan Masa Pajak Desember tahun 2013 terhadap Pengusaha Kena Pajak terdaftar tidak melebihi Rp. 4,8 Miliar, meyakinkan bahwa Pengusaha Kena Pajak tersebut memilih untuk dicabut pengukuhan Pengusaha Kena Pajaknya atau memilih untuk tetap dikukuhkan sebagai Pengusaha Kena Pajak dan melakukan pencabutan pengukuhan Pengusaha Kena Pajak pengusaha kecil yang memilih untuk dicabut pengukuhan Pengusaha Kena Pajaknya.

Kebijakan Ditjen Pajak melalui peraturan Nomor PER-12/PJ/2014 ternyata belum tersosialisasi dengan baik. Masih banyak PKP yang belum mengikuti pencabutan pengukuhan PKP karena banyak yang belum mengerti tujuan dari peraturan tersebut. Kebijakan ini dikeluarkan untuk mempermudah pengawasan. Penelitian ini didukung peneliti terdahulu oleh Arsita (2013), yaitu Analisis Rencana Perubahan Batas Omset Pengusaha Kena Pajak atas Pengenaan Pajak Pertambahan Nilai Usaha Kecil Menengah. Penelitian ini mengidentifikasi dan menganalisis latar belakang perubahan kebijakan atas omset per tahun menjadi PKP dan UKM. Untuk menyederhanakan pemajakan PPN pada UKM serta menyesuaikan dengan laju inflasi untuk menggairakan perekonomian negara. Demikian juga dengan peneliti Butar Butar (2013) mengenai Penerapan PP NO.46 Tahun 2013 Pada UMKM. Dampak penerapan PP No.46 Tahun 2013 terhadap besarnya PPh Badan yang harus dibayar oleh perusahaan.

Kesimpulan dari penelitian ini adalah penerapan peraturan baru memberikan kemudahan dalam pengawasan juga dalam menghitung besarnya PPh terhutang sehingga meminimalisir terjadinya kesalahan dalam menentukan besarnya PPh badan yang harus disetor dan juga untuk menyederhanakan pemajakan PPN pada UKM dan menyesuaikan dengan laju inflasi untuk menggairakan perekonomian negara. Jumlah penerimaan tergantung 
pada perubahan naik atau turunnya batas omset PKP. Pemerintah sebaiknya memberikan pengawasan pada UKM sehingga dapat menetapkan ketentuan kebijakan batas omset ideal.

\section{KESIMPULAN}

Kesimpulan dari penelitian ini adalah: KPP Pratama Manado melaksanakan pencabutan pengukuhan pengusaha kena pajak secara jabatan atas pengusaha kecil pajak pertambahan nilai tahun 2014 berdasarkan Peraturan Menteri Keuangan Nomor 197/PMK.03/2013 tentang Perubahan atas Peraturan Menteri Keuangan Nomor 68/ PMK.03/2010 tentang Batasan Pengusaha Kecil Pajak Pertambahan Nilai, batasan omset telah diubah menjadi tidak lebih dari Rp. 4.800.000.000,- (empat milyar delapan ratus juta rupiah).

Jumlah PKP Omset kurang dari Rp. 4.800.000.000,- di KPP Pratama Manado sebanyak 3.317 dari jumlah total PKP 4.405, dan tetap menjadi PKP sebesar 172 dan PKP dicabut sebesar 76. Belum semua PKP dengan jumlah diatas telah mengikuti pencabutan pengukuhan PKP dalam penerapan peraturan baru yang memberikan kemudahan dalam menghitung dan mengetahui peredaran bruto serta besarnya $\mathrm{PPh}$ terutang, sehingga meminimalisir terjadinya kesalahan dalam menentukan besarnya $\mathrm{PPh}$ Badan yang harus disetor. Selain penerimaan negara menjadi lebih pasti, dengan berlakunya peraturan baru yang dikeluarkan membantu pemerintah dalam pengelompokan pengenaan pajak, batasan omset dan pengawasan.

Saran yang dapat diberikan adalah: KPP Pratama Manado dalam pencabutan pengukuhan pengusaha kena pajak secara jabatan atas pengusaha kecil pajak pertambahan nilai tahun 2014 hendaknya tetap berpedoman pada peraturan yang berlaku dengan memperhatikan verifikasi dalam rangka pencabutan pengukuhan Pengusaha Kena Pajak dibagi menjadi 3 (tiga) tahapan, yaitu, Tahap Persiapan, Tahap Pelaksanaan, dan Tahap Pelaporan.

\section{DAFTAR PUSTAKA}

Arsita, Sari. (2013). Analisis Rencana Perubahan Batas Omset Pengusaha Kena Pajak atas Pengenaan Pajak Pertambahan Nilai Usaha Kecil Menengah. Skripsi. Universitas Indonesia. http://lib.ui.ac.id/opac/ui/detail.jsp?id=20331949\&lokasi=lokal. Diakses pada 7 Desember 2014. Hal 1-155

Butar Butar, Etha Y. A. (2013). Penerapan PP NO.46 Tahun 2013 Pada UMKM. Ejournal. Universitas

Brawijaya,

Malang.http://download.portalgaruda.org/article.php?article=189786\&val=6467\&title $=$ PENERAPAN\%20PP\%20NO.\%2046\%20TAHUN\%202013\%20PADA\%20UMKM \%20\%28Studi\%20Kasus\%20Pada\%20CV.\%20Lestari\%20Malang\%29. Diakses pada 4 Desember 2014. Hal 1-21

Indriantoro, Supomo. (2009). Metode Penelitian Bisnis untuk Akuntansi \& Bisnis. Edisi Pertama, BPFE, Yogyakarta.

Mardiasmo, (2013). Perpajakan . Edisi Revisi Tahun 2013. Penerbit Andi, Yogyakarta.

Pemerintah Republik Indonesia. (2014). Peraturan Direktur jendral Pajak Nomor PER 12/PJ/2014 tentang Pencabutan Pengukuhan Pengusaha Kena Pajak secara Jabatan atas Pengusaha Kecil Pajak Pertambahan Nilai, Jakarta.

Pemerintah Republik Indonesia. (2013). Peraturan Menteri Keuangan No.197/PMK.03/2013 tentang perubahan atas peraturan Menteri Keuangan No.68/PMK.03/2010 tentang batasan pengusaha kecil dalam pajak pertambahan nilai telah diubah menjadi tidak lebih 4,8 Miliar, Jakarta.

Resmi Siti, (2012). Perpajakan Teori dan Kasus. Edisi 6-Buku 1. Penerbit Salemba Empat, Jakarta.

Resmi Siti, (2012). Perpajakan Teori dan Kasus. Edisi 6-Buku 2. Penerbit Salemba Empat, Jakarta. 
Sugiyono, (2010). Metode Penelitian Bisnis (Pendekatan Kuantitatif, Kualitatif dan R\&D). ALFABETA, Bandung.

Waluyo, (2011). Perpajakan Indonesia. Edisi 10-buku 1. Salemba Empat, Jakarta. Waluyo, ( 2011). Perpajakan Indonesia. Edisi 10-buku 2. Salemba Empat, Jakarta. Waluyo, (2012). Akuntansi Pajak. Edisi 4. Salemba Empat, Jakarta. 